\title{
Dynamics and management alternatives of in-channel large wood in mountain basins of the southern Andes
}

\author{
Dinámica y alternativas de manejo de material leñoso de gran tamaño \\ en cuencas del sur de Los Andes
}

\author{
Luca Mao a*, Andrea Andreoli b, Andrés Iroumé c, Francesco Comiti d, Mario A Lenzi ${ }^{\mathrm{e}}$ \\ *Autor de correspondencia: ${ }^{\text {a }}$ Pontificia Universidad Católica de Chile, Departamento de Ecosistemas y Medio Ambiente, Vicuña \\ Mackenna 4860, Macul, Santiago, Chile, lmao@uc.cl \\ ${ }^{\mathrm{b}}$ Universidad de Concepción, Facultad de Ciencias Forestales, Departamento Manejo de Bosques y Medio Ambiente, Concepción, Chile. \\ ${ }^{c}$ Universidad Austral de Chile, Facultad de Ciencias Forestales y Recursos Naturales, Instituto de Conservación, \\ Biodiversidad y Territorio, Valdivia, Chile. \\ ${ }^{\mathrm{d}}$ Free University of Bozen-Bolzano, Faculty of Science and Technology, Bozen-Bolzano, Italia. \\ ${ }^{\mathrm{e}}$ Università di Padova, Dipartimento Territorio e Sistemi Agro-Forestali, Italia.
}

\begin{abstract}
SUMMARY
Large wood has a positive effect on channel morphodynamics and freshwater biodiversity of mountain streams. However, its presence can enhance the risks associated with extreme flood events in inhabited floodplains. This study reports on wood abundance, spatial distribution, recruitment and depositional mechanisms in three third-order basins of south-eastern Andes (Tres Arroyos, Río Toro and Buena Esperanza). Major differences in large wood loads and quantity exist among the analyzed basins, due to different disturbance history and forest cover features. Marked logs in Buena Esperanza and Tres Arroyos were surveyed before and after floods. Ordinary events (recurrence interval $<2$ years) moved only small and isolated $\operatorname{logs}$ (diameter $<0.25 \mathrm{~m}$; length $<3$ m) and for relatively short distances. The reported study basins are taken as paradigmatic cases to illustrate a management strategy for hazards associated with wood transport during major floods. Log removal and riparian vegetation cuts are not effective strategies because high-magnitude, infrequent events are able to recruit trees from hillslopes due to mass wasting processes. Flood-prone area should be preserved free from sensitive settlements. However, important localized infrastructures can be protected with specifically designed structural solutions. Their potential use in the context of the three analyzed Andean basins is discussed.
\end{abstract}

Key words: large wood load, mountain streams, in-channel wood management, check dams.

\section{RESUMEN}

Los elementos leñosos tienen un efecto positivo en la morfodinámica de los canales y en la biodiversidad de los cauces de montaña. Sin embargo, su presencia puede aumentar los riesgos asociados a las inundaciones extremas en las llanuras pobladas. Este estudio reporta acerca de la abundancia, la distribución espacial, los mecanismos de incorporación y deposición de los elementos leñosos entre cuencas del sureste de los Andes (Tres Arroyos, Río Toro, y Buena Esperanza). Los resultados muestran grandes diferencias entre las cantidades y los volúmenes de elementos leñosos de las cuencas analizadas, debido a las diferentes perturbaciones históricas y a las distintas características de cubierta del bosque. Para estimar la movilidad de las piezas leñosas, estas fueron marcadas en el Buena Esperanza y en el Tres Arroyos. Los eventos ordinarios (intervalo de recurrencia menores de dos años) movieron solo elementos pequeños y aislados (diámetro $<0,25 \mathrm{~m}$, longitud $<3 \mathrm{~m}$ ) y para distancias relativamente cortas. Las cuencas de estudio reportadas son tomadas como casos paradigmáticos para ilustrar una estrategia de gestión de elementos leñosos. La eliminación de los elementos y los cortes de la vegetación ribereña, no son estrategias eficaces, porque los raros eventos de gran magnitud son capaces de movilizar los árboles de las laderas por remoción en masa. Áreas propensas a inundaciones deben ser preservadas libres de asentamientos sensibles. Sin embargo, importantes infraestructuras presentes pueden ser protegidas con soluciones estructurales específicamente diseñadas. Su potencial uso en el contexto de las tres cuencas andinas analizadas es presentado en este trabajo.

Palabras clave: material leñoso, cauces de montaña, manejo de material leñoso, diques.

\section{INTRODUCTION}

In forested basins, large pieces of wood (length $>1 \mathrm{~m}$; diameter $>0.1 \mathrm{~m}$; hereafter LW) lying on river beds are able to increase the morphological diversity and the dynamics of the river network. Overall, LW has a benefi- cial influence on in-channel and riparian biodiversity and abundance because it enhances the ecological properties of both the active channel and the entire river corridor (Collier and Halliday 2000). The positive effects of LW are mainly due to the increased morphological diversity exerted at a variety of scales (Gurnell et al. 2002). Also, 
especially when organized in jams or accumulations, LW can strongly affect flow hydraulics and transport/storage of sediments within the channel system, thus conditioning channel dimensions (Nakamura and Swanson 1993) and typology and distribution of bedforms, increasing the heterogeneity and quality of the stream habitats and the biological diversity of aquatic organisms (Chen et al. 2008, Vera et al. 2012). However, river management agencies and the public tend to perceive LW as an obstacle to navigation, and as a source of potential clogging of bridges and hazards during flood events (Chin et al. 2008). As a consequence, the traditional strategy for managing in-channel LW basically consisted of removing dead wood from the river corridor and often on cutting vegetation from islands and floodplains. This has been largely the case in Europe (Comiti et al. 2006) and, with less impact, in North America (Mcllroy et al. 2008). However, in order to maintain and restore the morphological and ecological processes of river systems, a different set of management practices have recently been trialed. In fact, current attempts are made to promote natural recovery processes such as allowing bank erosion and thus wood recruitment into rivers (Rinaldi et al. 2009). Natural or engineered wood pieces have even been artificially reintroduced into channels deprived of naturally-recruited LW (Gerhard and Reich 2000) in order to increase the morphology and habitat complexity (Kail et al. 2007). However, it has been pointed out that the most sustainable option is the restoration of a natural wood cycle which includes wood input from slopes and banks, transport, deposition and mobilization.

Besides the proven positive effects of dead wood in river systems, in densely populated areas LW could exacerbate the damages associated with high magnitude floods. In fact, LW as part of debris flows in small mountain streams can create temporary jams which often collapse during flood events; they can also accumulate on bridge piers and create local bed scour and bank erosion. However, the risks associated with LW are strongly dependent on the degree of human presence within a catchment such as the frequency and type of road crossings, and the proximity and density of human settlements adjacent to the channels. Therefore, it is evident how a balanced, integrated management of LW and of potential sources of wood to the adjacent input areas is needed. To do so, a better understanding of the dynamics of recruitment, transport and deposition of LW in mountain basins is crucial for developing adaptive management of the potential hazards of LW to human communities and infrastructure. Furthermore, an ecologically-oriented management approach is especially required for mountain basins still presenting a high degree of naturalness.

Despite its great relevance for freshwater ecosystems and river management, in-channel wood abundance, distribution, dimension and mobility are relatively unknown in the temperate region of the Latin American continent. Although LW abundance and associated river morphology have been described in five Andean streams (Andreo- li et al. 2008, Comiti et al. 2008, Ulloa et al. 2011), no attempts of incorporating wood presence and mobility in river management strategies have been made. The present paper presents a comprehensive description of LW amount and mobility in steep channels of the Southern Andes, built on both published (Andreoli et al. 2008, Comiti et al. 2008) and unpublished results. Three study basins were selected as representative of small $\left(\sim 10 \mathrm{~km}^{2}\right)$ Andean basins characterized by a range of forest cover and climatic conditions. The main goals of the paper are to examine LW recruitment mechanisms, degree of mobility and depositional sites for basins with different forest cover and to suggest a range of adaptive LW management approaches.

\section{METHODS}

Study basins. The study was carried out on three Andean basins: Tres Arroyos (TA) and Rio Toro (TO) lie in the Chilean Araucania region; whereas Buena Esperanza (BE) is located in the Argentinean Tierra del Fuego near the city of Ushuaia (table 1, figure 1). The three basins are different regarding forest cover and past disturbances (i.e. wildfires and debris flow events), and also in terms of degree of human presence and pressure.

Tres Arroyos basin is $72 \%$ forested, and nearly a third of this area is represented by native old-growth $(>40-50 \mathrm{~m}$ tall; > 1-2 m diameter; $>500$ years old) araucaria forest (Araucaria araucana (Mol.) K. Koch). The remaining area is characterized by unvegetated sandy volcanic ashes (near the upper watershed division, $6 \%$ ) and herbaceous-shrub cover (near the tree-line limit, $22 \%$ ). An extended wildfire occurred at the beginning of the last century within Tres Arroyos basin. As a consequence, the basin is now heavily affected by debris flows, which deliver significant amounts of wood in steep tributaries draining the burned area as a consequence of hillslope destabilization, resulting from lack of forest cover. Hydrology and sediment transport in Tres Arroyos has been monitored since 1997 (Andreoli et al. 2008). A previous analysis of in-channel wood characteristics in Tres Arroyos is presented by Andreoli et al. (2008).

Toro basin was almost completely ( $95 \%$ ) covered with old-growth stands of the Coihue-Raulí-Tepa forest type (Donoso 1981), characterized by Nothofagus dombeyi (Mirb.) Oerst. (coihue), Nothofagus nervosa Phil (raulí) and Laureliopsis philippiana Looser (tepa), up to 2002, when catastrophic wildfires burned $98 \%$ of the forest cover. The burned trees are still standing, and no hillslopes instabilities have taken place yet in the basin (Comiti et al. 2008). Indeed, fire is the most important disturbance shaping the Araucaria-Nothofagus landscape in the Araucarian region (Gonzalez et al. 2005). During the 2001-02 fire seasons, catastrophic fires burned nearly 20,000 ha of temperate forests in the Andean Araucaria region of Chile. Recent studies (González et al. 2005) have determined that extensive fires of such kind lie within the range of the historic fire regimes that have shaped this forested landscape. 
Table 1. Main characteristics of the study basins. Características de las cuencas de estudio.

\begin{tabular}{lccc}
\hline \multicolumn{1}{c}{ Basin characteristics } & Tres Arroyos (TA) & Toro (TO) & Buena Esperanza (BE) \\
\hline Basin Area $\left(\mathrm{km}^{2}\right)$ & 9.1 & 11.1 & 12.9 \\
Mean basin slope (\%) & 43 & 20 & 23 \\
Climate & Temperate warm humid & Temperate warm humid & Temperate cold humid \\
Hydrological regime & pluvial/nival & pluvial/nival & glacionival \\
Annual precipitation & 2,217 & 2,480 & $530 / 1,300$ \\
Geology & Volcanic / pyroclastic & Volcanic / & Sedimentary/ \\
Forest cover $(\%)$ & 74 & pyroclastic & Metamorphic \\
& Nothofagus dombeyi / & Nothofagus dombeyi / & 34 \\
Dominant forest species & Nothofagus nervosa / & Nothofagus pumillo / \\
& Araucaria araucana & Laureliopsis philippiana & Nothofagus antarctica \\
Forest disturbances & Wildfire (1930's) & Wildfire (2002) & Wind blowdowns \\
Dominant channel morphology & Step-pool / cascade & Plane-bed / step-pol & Cascade / step-pool \\
Total channel length $(\mathrm{km})$ & 4.9 & 7 & 7.5 \\
Surveyed channel length $(\mathrm{km})$ & 1.5 & 2.2 & 1.9 \\
Number of surveyed reaches & 17 & 17 & 33 \\
Average channel slope $(\mathrm{m} / \mathrm{m}) *$ & 0.08 & 0.05 & 0.065 \\
Average channel width $(\mathrm{m}) *$ & $7-7$ & 11.9 & 6.3 \\
\hline
\end{tabular}

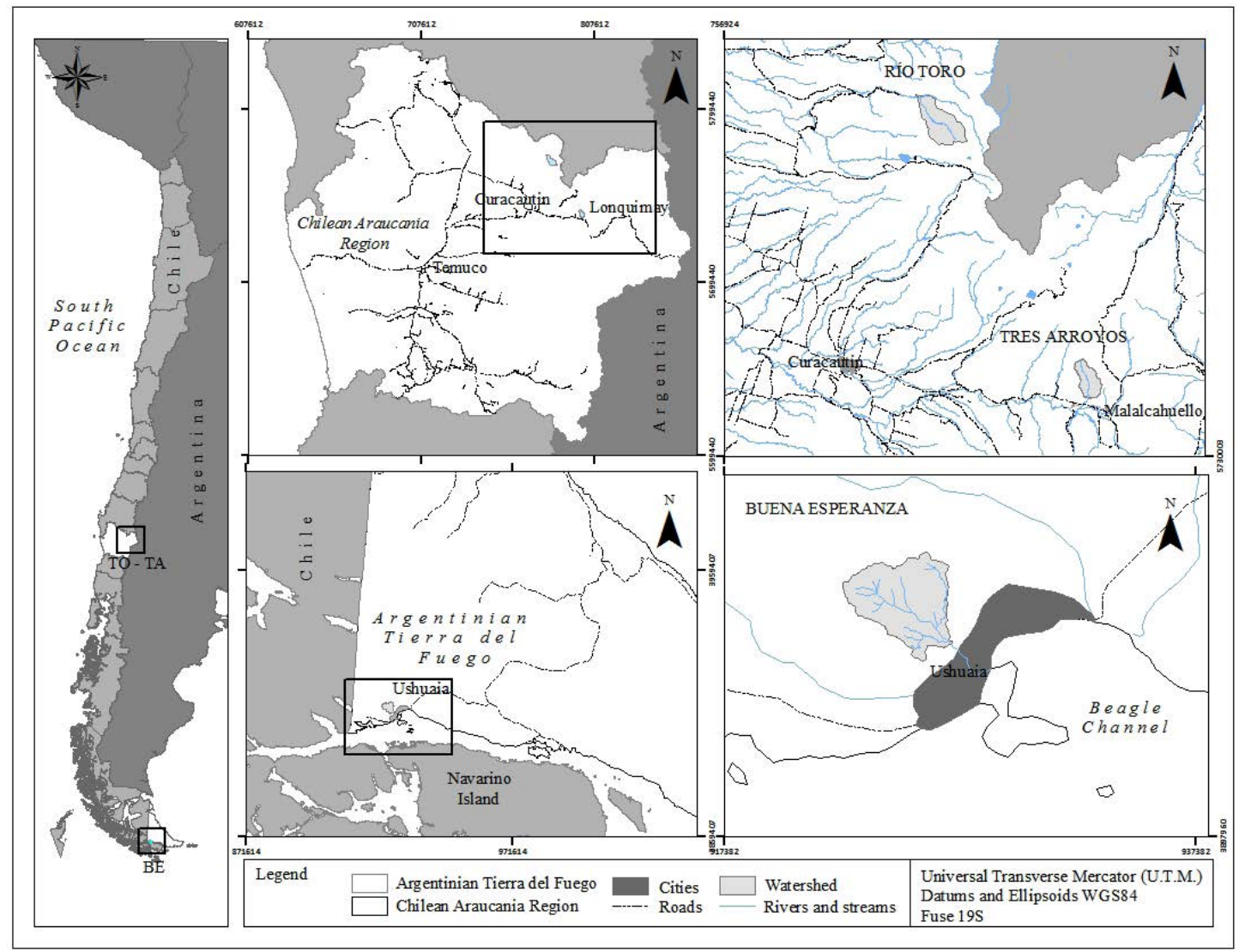

Figure 1. Location of the study basins. Localización de las cuencas en estudio. 
The third basin is Buena Esperanza, which is located in front of the Beagle Channel (Tierra del Fuego), above the city of Ushuaia. The regime is glacio-nival due to the presence of a small glacier in the uppermost portion of the catchment. In Tierra del Fuego, the vast majority of river basins $(98 \%)$ are heavily impacted by the damming activity of beavers (Castor canadensis Kuhl), which were artificially introduced in 1946. The study basin of Buena Esperanza represents one of the few channels not impacted by these mammals. Only $34 \%$ of the drainage area is covered by forest, the rest lying above the tree-line. Forest cover is characterized by a relatively simple association of three Nothofagus species (Nothofagus pumillo (Poepp et Endl.) Krasser, Nothofagus antarctica Forster, and Nothofagus betuloides (Mirb) Blume), which are strongly influenced by the extreme climatic conditions. The very slow tree growth and the periodic windthrows produce a forest composed by mature trees with diameters as small as $30 \mathrm{~cm}$. At present, no forest harvesting is allowed in Buena Esperanza; whereas some occasional logging was conducted in the past, especially during the 1940 s. All the basins do not present significant difference between forest cover and riparian forest. However, the three basins are fundamentally different in terms of human infrastructures and settlements, and so they require different strategies for LW and riparian vegetation management. Tres Arroyos basin is virtually free from human activities, though an important road and a small but rapidly growing settlement are located at the outlet of the basin. Severe debris flow events occurred in 1972 and 1992 causing serious damages to the road and infrastructures. The lack of hydrological data does not allow estimating de magnitude of the floods and its capability to mobilize logs. Local people living on the alluvial fan of Tres Arroyos claim that LW was crucial for the dynamics of the 1992 flooding by clogging the small bridge at the end of the alluvial fan and reducing the stream section, hence allowing greater accumulation of sediment thus causing channel overflow. In this event huge quantities of LW were deposited on the alluvial fan (Andreoli et al. 2008). On the other hand, Río Toro is virtually free of human settlements or infrastructures, both in the basin and at its junction to the higher-order river. Buena Esperanza basin is characterized by many human settlements, of which the most notable is the fast-growing city of Ushuaia in its lower portion. Many streets and infrastructures cross the main channel and few touristic settlements are relatively close to it. Furthermore, Buena Esperanza represents the main supply of drinking water for the city of Ushuaia by direct extraction, and the local administration is particularly enthusiastic to avoid sedimentation or damage due to transported logs to the water intake structures in the main channel.

Survey methods. The study channels were surveyed in March-April 2005 (Tres Arroyos, TA), January 2006 (Toro, TO) and February-March 2006 (Buena Esperanza, BE). The longitudinal profile of the study reaches were measured using a laser distance meter with inclinometer (estimated precision $\leq 1 \mathrm{~mm}$ ). Individual sub-reaches were defined based on uniformity of either slope, channel width or abundance of LW. Mean bankfull and floodplain (or fluvial corridor) width and mean bankfull depth were measured in up to three cross-sections on each stream reach. All wood pieces greater than $10 \mathrm{~cm}$ in diameter and $1 \mathrm{~m}$ in length (as commonly done in previous works, e.g. Abbe and Montgomery 2003, Faustini and Jones 2003) were measured in the active channel (i.e., within the bankfull width) and in the adjacent active floodplain throughout the surveyed channel length reported in table 1 . Overall, more than 5,500 logs were measured. The length and mid-diameter of each log were measured with a tape and a tree caliper, respectively (estimated precision $\leq 1 \mathrm{~cm}$ for diameter and $\leq 5 \mathrm{~cm}$ for length). The volume of each wood log was calculated assuming a solid cylindrical shape, as commonly done in LW studies. Additional data were recorded for each wood piece during the field survey, such as type (i.e., log, rootwad, log with rootwads), orientation to flow (parallel, orthogonal, oblique) and recruitment mechanism (bank erosion, landslide, natural mortality, floated from upstream). For further details on the data collected in the field see Comiti et al. (2008).

A certain number of LW pieces were tagged in Tres Arroyos and Buena Esperanza in order to investigate LW mobility and displacement length during floods. Their position before and after flood was taken measuring the distance from numbered wooden stacks located along the main channel. More than one tag per log was used for long ( $>4 \mathrm{~m}$ ) or multi-stemmed LW pieces. The logs were chosen to be representative of the full size distribution above the minimum dimension (for both diameter and length) on both streams. The length and diameter of tagged LW pieces were measured, and supplementary data were collected about position within the channel, orientation to flow, inclusion in jams, decay status and degree of anchoring (e.g. by logs, boulders, banks). A total of 322 wood pieces of different size were marked and numbered with metal tags in Tres Arroyos in March 2005, and 380 logs were tagged in Buena Esperanza in March 2006, which represent the $14 \%$ and $16 \%$ of the total measured LW pieces within Tres Arroyos and Buena Esperanza, respectively. The position of tagged logs in Tres Arroyos was re-surveyed in December 2005 after a near-bankfull event $\left(4.2 \mathrm{~m}^{3} \mathrm{~s}^{-1}\right)$. Similarly, in Buena Esperanza wood displacement was surveyed about one year (March 2007) after tagging. In this period, the channel experienced two ordinary (recurrence interval $\sim 1$ year) flood events $\left(2.43 \mathrm{~m}^{3} \mathrm{~s}^{-1}\right.$ and $\left.2.40 \mathrm{~m}^{3} \mathrm{~s}^{-1}\right)$.

\section{RESULTS}

Wood abundance and recruitment mechanisms. LW load and abundance within the active channel vary substantially on the three study sites (figure 2). Buena Esperanza shows the highest number of LW pieces in the channel $(1,400$ pieces $\left.\mathrm{ha}^{-1}\right)$. However, if the LW volume per channel unit 
area is considered, Tres Arroyos features the largest value $\left(>700 \mathrm{~m}^{3} \mathrm{ha}^{-1}\right)$. Río Toro has the lowest LW loads, both in terms of LW abundance and volume (215 pieces ha $\mathrm{ha}^{-1}$ and $117 \mathrm{~m}^{3} \mathrm{ha}^{-1}$, respectively). Interestingly, Buena Esperanza shows the highest number of LW pieces but the smaller volume of wood per channel unit (figure 2).

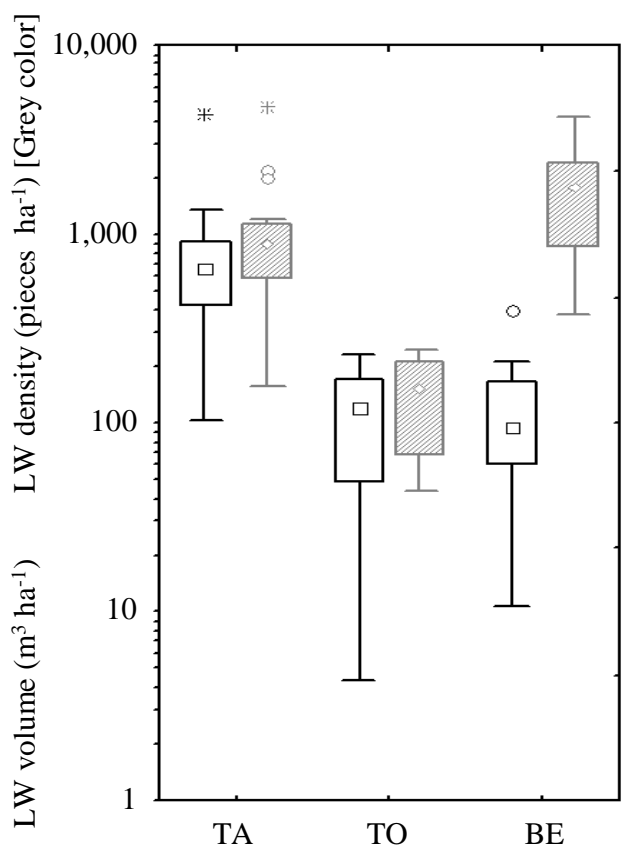

Figure 2. Box and whisker plots of the amount and volume of LW within the active channel of the three study channels. The line within each box indicates the median value, box ends are the $25^{\text {th }}$ and $75^{\text {th }}$ percentiles, and whiskers ends are the 10th and 90th percentiles (TA Tres Arroyos; TO Río Toro, BE Buena Esperanza).

Abundancia y volumen de material leñoso en los cauces activos en las tres cuencas en estudio. Las líneas en los diagramas de caja representan el valor mediano, la caja los percentiles 25 y 75 , y los bigotes son los percentiles 10 y 90 (TA Tres Arroyos; TO Río Toro, BE Buena Esperanza).
On both Tres Arroyos and Río Toro streams, $68 \%$ of LW pieces are jammed forming wood accumulations. However, Tres Arroyos features more and bigger wood jams than those featured by Río Toro (table 2). Also, jams are formed by the accumulation of more logs in the former than in the latter stream. An enormous accumulation of LW (gross geometrical volume $\sim 600 \mathrm{~m}^{3}$ ), formed by almost 100 wood pieces $0.5 \mathrm{~m}$ in diameter and $4-5 \mathrm{~m}$ long on average, lies at the confluence with a debris flow channel (figure 3). The location of the valley jams is clearly linked to external forcing such as landslides, actively eroded banks and the confluences with debris flow channels, which provide the main channel with large, nearly immobile LW pieces able to build up a large transverse jam structure, trapping smaller wood pieces (Andreoli et al. 2008).

In the sub-Antarctic climate of Tierra del Fuego, wood rarely reaches large dimensions (Comiti et al. 2008) as in other regions of the Southern Andes, and LW pieces are small and finer (table 2). However because of the windand storm-caused damage to trees, considerable LW is supplied to the river network, therefore LW jams are as abundant as in Tres Arroyos (55 and 51 jams per km length of channel, respectively). Despite the smaller size, LW jams in Buena Esperanza can be very effective in retaining sediments and scouring pools.

Wood mobility and transport distance. In Buena Esperanza, during the second field-survey 61 of the 380 marked pieces of wood were not found in their original position and it is assumed they were transported by the highest registered discharge recorded between the first and the second survey. Because the flood magnitude $\left(2.43 \mathrm{~m}^{3} \mathrm{~s}^{-1}\right)$ is very close to the field-identified bankfull discharge, it is not surprising that 59 of the 61 moved pieces of wood were originally lying within the active channel. The transported pieces have diameters ranging between 0.1 and $0.65 \mathrm{~m}$, with $85 \%$ of them having $\mathrm{D}_{\text {wood }}<0.25 \mathrm{~m}$ (figure 4 ). In total

Table 2. Main characteristics and dimensions of LW pieces and LW jams on the active channels of the study channels.

Características y dimensiones de troncos y acumulaciones de material leñoso en los cauces activos de las cuencas de estudio.

\begin{tabular}{lccc}
\hline \multicolumn{1}{c}{ Parameter } & Tres Arroyos (TA) & Río Toro (TO) & Buena Esperanza (BE) \\
\hline Maximum diameter $(\mathrm{m})$ & 1.2 & 1.2 & 0.90 \\
Mean diameter $(\mathrm{m})$ & 0.50 & 0.33 & 0.18 \\
Maximum length (m) & 25.7 & 15 & 17 \\
Mean length (m) & 3.0 & 3.62 & 0.50 \\
Maximum piece volume $\left(\mathrm{m}^{3}\right)$ & 24.86 & 12.43 & 6.68 \\
Mean piece volume $\left(\mathrm{m}^{3}\right)$ & 0.70 & 0.56 & 0.13 \\
Number of jams per km & 51 & 19 & 55 \\
Number of pieces per jam* & $15(2-93)$ & $12(3-47)$ & $11(3-57)$ \\
Volume of wood jams* & $9(0.2-68)$ & $6.5(0.2-20)$ & $1.4(0.1-8.1)$ \\
\hline
\end{tabular}

*Average value and ranges (in brackets). 

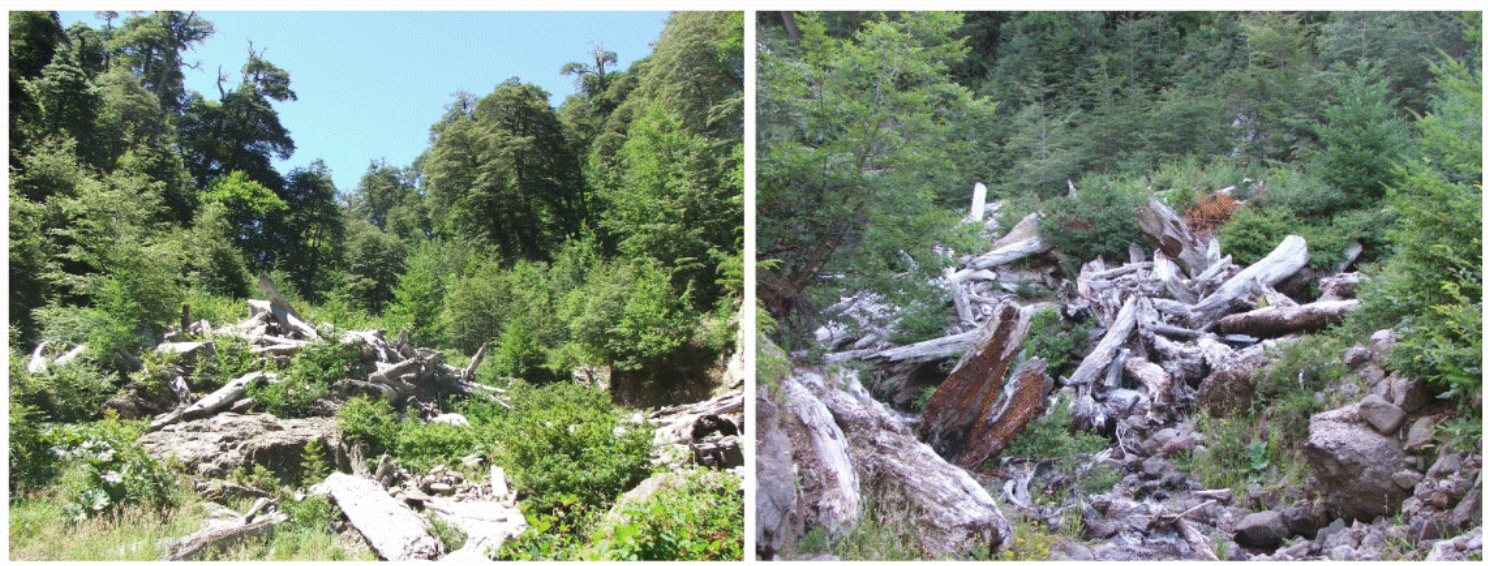

Figure 3. Valley jams in Tres Arroyos main channel. The largest LW in the photo is $N$. dombeyi with $120 \mathrm{~cm}$ in diameter and $10 \mathrm{~m}$ of length, and accumulation is some $3 \mathrm{~m}$ height and $15 \mathrm{~m}$ wide.

Acumulaciones de material leñoso en el cauce del Tres Arroyos. El elemento de mayor tamaño es un $N$. dombeyi, con un largo de $10 \mathrm{~m}$ y $120 \mathrm{~cm}$ de diámetro, y la acumulación es de unos $3 \mathrm{~m}$ de altura y15 $\mathrm{m}$ de ancho.

$90 \%$ of the transported pieces were shorter than $3 \mathrm{~m}$ (figure 4) and only $19 \%$ of all the moved pieces were part of jams. Only 38 pieces of wood were recovered after flood; $63 \%$ of them were found parallel to the flow direction and not trapped in accumulations. The missing pieces were most probably transported downstream of the study reach.

Regarding Tres Arroyos, 22 marked pieces of wood were transported by a flood of $4.2 \mathrm{~m}^{3} \mathrm{~s}^{-1}$, slightly higher than bankfull discharge. Apart from a very large piece $\left(\mathrm{L}_{\text {wood }}=\right.$ $9.1 \mathrm{~m}$; $\mathrm{D}_{\text {wood }}=0.55$ ) transported for $24 \mathrm{~m}$, the moved pieces have diameters ranging between 0.15 and $0.45 \mathrm{~m}$ and length between 0.6 to $5.3 \mathrm{~m}$. In this case, just eight pieces were recovered after the flood and only one of them was found jammed with other pieces, with the others deposited on bars and channel margins (figure 5).

\section{DISCUSSION}

Wood abundance and recruitment mechanisms. The total amount of LW load in Tres Arroyos is very high $\left(>700 \mathrm{~m}^{3}\right.$ $\mathrm{ha}^{-1}$ ), and similar high values have been reported only for old-growth redwood forests in the Pacific Northwest $\left(\sim 1,000 \mathrm{~m}^{3} \mathrm{ha}^{-1}\right.$; Fox and Bolton 2007). On the other hand, the relatively low LW volume stored in Buena Esperanza $\left(\sim 100 \mathrm{~m}^{3} \mathrm{ha}^{-1}\right)$ is due to the small dimension of LW pieces (table 2), caused by the extremely slow growth of Nothofagus spp. in Tierra del Fuego (Comiti et al. 2008). Because the LW pieces lying on Río Toro and Tres Arroyos are of similar sizes (table 2), the difference in terms of LW load on their channels (figure 2) is most likely due to the relatively low supply of wood to the Rio Toro channel. In the Araucania region, fires control forest regeneration and thus the supply of LW to the channel network. However, LW load can increase with a lag time of several decades after a wildfire (Zelt and Wohl 2004). This may explain why wood volumes are so different between Río Toro -where $98 \%$ of the forests burned in 2002- and Tres Arroyos, which is now heavily affected by landslides as a consequence of fires occurred almost a century ago. In Río Toro the burned trees are mainly still standing and no considerable slopes instabilities (landslides and debris-flows) delivered wood to the river network; likely due to more gentle hillslopes and lack of slide-trigging storms. In contrast, in Tres Arroyos the loss of forest cover caused severe landslides and debrisflows, which supplied a huge amount of LW to the channel.

Wood mobility and transport distance. Considering the transport of marked logs, results confirm that during ordinary events (recurrence interval $<2 y$ ), the transport of LW is essentially limited to small and isolated pieces. The woody jams are stable and the morphologic impact of the transport of floating material is virtually negligible. Differences observed between wood mobility in Tres Arroyos and Buena Esperanza reflect their diversity in terms of dimension of in-channel LW, which is the result of the very different growth rates of native forests, due to climatic constraints in the sub-Antarctic basin of Buena Esperanza (Comiti et al. 2008). For Tres Arroyos there is a decreasing trend, with larger diameter wood travelling less distance whereas in the case of Buena Esperanza there is no pattern (figure 5). This result confirms previous field studies conducted in low-order streams (Nakamura and Swanson 1993) which showed that smaller pieces move farther than larger pieces, and that most mobile pieces are shorter than the bankfull width. Also, piece diameter strongly influences the flow depth required to entrain and transport logs, thereby influencing travel distance (Abbe and Montgomery 2003).

Overall, the results show that the LW pieces lying on the river bed of first-order streams are rather stable du- 

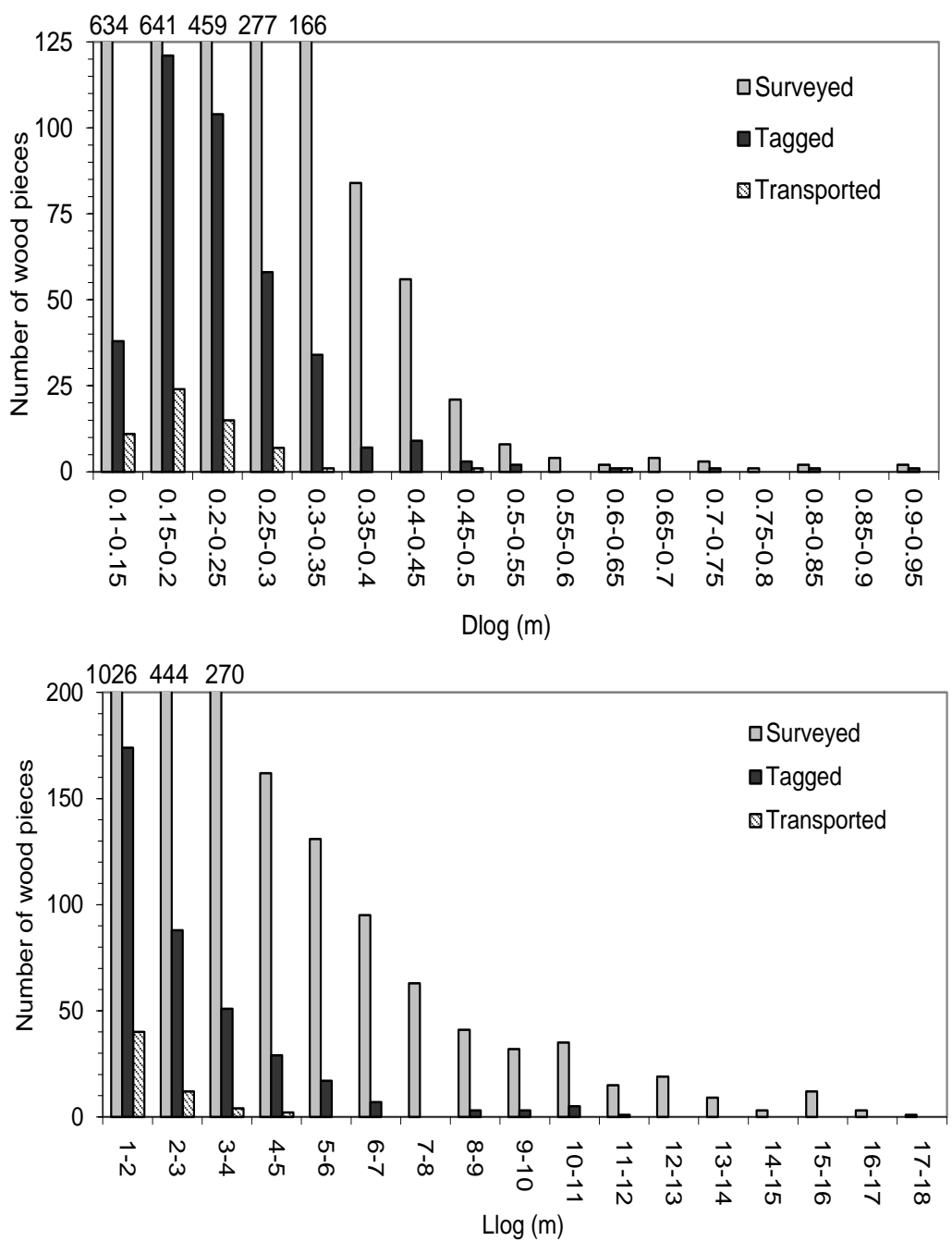

Figure 4. Frequency distribution of diameter and length size of the all surveyed wood found in Buena Esperanza main channel, as well as tagged and transported wood (transported by a near-bankfull flood of $2.43 \mathrm{~m}^{3} \mathrm{~s}^{-1}$ ).

Distribución de la abundancia de material leñoso para las clases de diámetro y longitud del total de elementos en el Buena Esperanza, del material marcado conchapas metálicas, y del material transportado por una crecida de $2,43 \mathrm{~m}^{3} \mathrm{~s}^{-1}$.

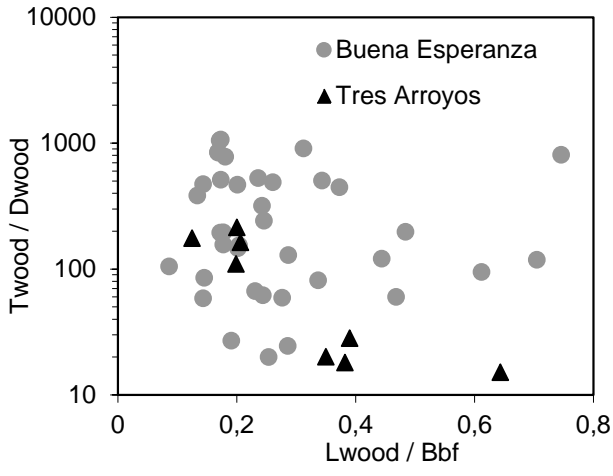

Figure 5. Relationship between the wood travel distance (relative to their diameter) (Twood/Dwood) and length (relative to the bankfull channel width) (Lwood/Bbf).

Relación entre distancia de transporte (relativo al diámetro del tronco) y longitud del tronco (relativa al ancho del canal). ring low to moderate flow events. In the third-order Mack creek (Oregon, USA) long-term research showed that less than $1 \%$ of $\log$ pieces moved annually, and that a major flood ( $25 \mathrm{y}$ return period) caused only $11 \%$ of wood pieces to move, mostly for less than $10 \mathrm{~m}$ (Gurnell et al. 2002). All pieces that moved during the 14 year-long record were shorter than the bankfull width, and most pieces that moved more than $300 \mathrm{~m}$ were shorter than two meters. Berg et al. (1998) confirmed that less than $1 \%$ of tagged wood pieces moved in 6 streams in California Sierra Nevada (2 to $13 \mathrm{~m}$ bankfull width) after one year of moderate flows. During a following year characterized by higherthan average flows, $31 \%$ of log pieces were transported.

Wohl and Goode (2008) reported divergent results from a long term monitoring study of wood mobility in five Colorado Rocky Mountain streams (basin areas between 9 and $32 \mathrm{~km}^{2}$ ). The average residence time of wood pieces was re- 
latively short (three to four years), but logs were relatively small (average D of $0.15 \mathrm{~m}$ and L of $3.2 \mathrm{~m}$ ). Wohl and Goode (2008) also report that the presence of wood jams sensibly increases the residence time of wood in the study streams. Interestingly, Ulloa et al. (2011) reported that $12 \%$ of the wood pieces tagged in Vuelta de Zorra (Chile) were transported due to bankfull floods. Even if no significant relationships were found between piece length/bankfull width with travelled distance/piece diameter, all the transported LW in Vuelta de Zorra were shorter than the bankfull width and the mean travelled distance was about $117 \mathrm{~m}$ (Ulloa et al. 2011).

Management options for in-channel wood. The previous sections showed that the mobility of wood in mountain streams is relatively reduced during ordinary floods (e.g. near-bankfull events). As a consequence, for most of the time wood lie relatively stable in the channel stabilizing the bed, limiting sediment transport and providing habitats for freshwater and riparian communities. Even if in mature and old-growth forests wood can be slowly and continuously delivered to the river network from natural mortality, relevant in-channel wood transport and wood recruitment from slopes and eroded banks usually takes place only during high magnitude floods. Overall, wood exerts long-lasting eco-hydro-morphological effects on streams, becoming potentially hazardous to human infrastructure only during short and infrequent high-magnitude events. However, the removal of wood and riparian trees from the channels and the floodplains has been the traditional way of reducing the wood related hazards, such as bridge clogging and overflow due to higher flow resistance. However this approach is not sustainable as it is ineffective, very expensive and creates negative effects on stream morphology, stability, ecological status and fish population.

Many rivers draining the temperate Andes still maintain high geomorphologic and ecological richness partly due to the natural presence of wood in the stream network. This will continue in the future as native forests established on soils of forests aptitude cannot be transformed into plantations or grasslands according to the Chilean legislation. At the same time, despite a relatively short history of river intervention, many southern Andean rivers now suffer from different ranges and intensities of human disturbances (land-use change associated with increases in forest planted areas, channelization, hydropower generation, damming and gravel mining), which have altered river morphology and dynamics. Also, flood risk is generally increasing because more infrastructures are built within fluvial corridors and on alluvial fans, which are naturally subject to potentially dangerous transport of sediment and wood during major flood events (i.e., recurrence interval $>20-30$ years).

There are several alternatives for in-channel wood management, considering both the non-structural solution and structural alternatives. These considerations are organized as a flow chart (figure 6), and are to be considered appropriate for small basins $\left(<200-300 \mathrm{~km}^{2}\right)$.
Non-structural alternatives. The more obvious management option against flood risk, including mobile large wood, is to avoid building any valuable structures in flood-prone areas, i.e. the adoption of a careful land use planning. Removal of dead wood and living standing trees from the channel corridor should be carried out only locally, where a dangerous jam can potentially form. However, for structures already located within the fluvial corridor because of ill-advised decisions of the past, priority should be given to assess whether the structure can be relocated. For minor infrastructure, debris sweepers vertically adjusted to the upstream side of bridge piers and racks at culverts might be enough.

If infrastructure of major relevance cannot be relocated and wood could represent a significant hazard during major floods (i.e., recurrence interval $>20$-30 years), in-channel wood removal is not recognized to be an effective countermeasure. In fact, during major floods, bank erosion, landslides and debris-flows from tributaries usually take place, recruiting fresh wood to the river network. Also, the location of potential wood recruitment sites during floods is still relatively difficult to predict (Mazzorana et al. 2009, 2011) and the estimation of the longitudinal patterns of wood distribution in forested headwater streams is still an issue (Rigon et al. 2012). As a consequence, the adoption of structural countermeasures would be needed, after a sound evaluation of where and how much wood could potentially enter the network, as well as where critical cross-sections for obstructions are situated. Because these control works can be expensive, their installation should be localized and site-specific, and their construction must be justified by a cost-benefit analysis.

Structural alternatives. In-channel control works for retention of wood transported during major floods have been mainly developed in the densely-populated European and Japanese Alps. The choice of the most appropriate retention structure depends on channel width and on the amount of large wood potentially transportable by expected flood events. As previously pointed out, LW volume is highly variable between basins, but can be evaluated through field surveys (Comiti et al. 2008), interpretation of aerial photos and airborne multispectral imagery (Marcus et al. 2002). Also, semi-empirical models, which allow the estimation of wood recruitment from bank and floodplains, the likeliness of landslides to occur and deliver wood to the channel and the evaluation of wood entrainment and transport along the river network, are increasingly available (Mazzorana et al. 2009, 2011, Rigon et al. 2012).

Structural solutions potentially adoptable for retaining in-channel wood in Southern Andes mountain streams could include filter concrete check dams, rope net barriers and cable filter dams. Filter check dams are commonly built in the European Alps to "break" debris flows and to store the coarser fraction of the transported sediments. With modifications such as inclined buttresses and grids (figure 7A), wood-oriented check dams have been develo- 


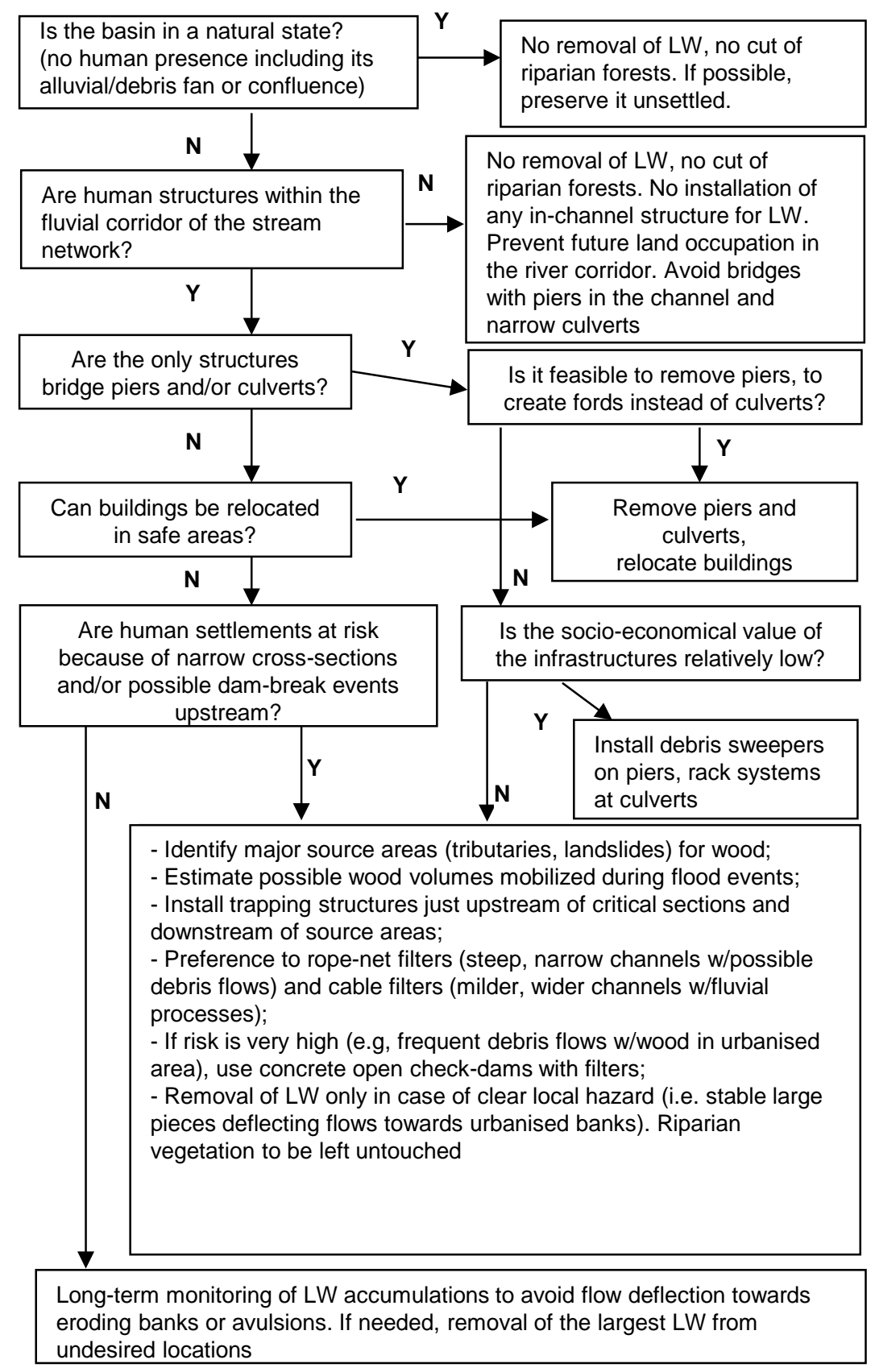

Figure 6. Possible options for Large wood management in small basins $\left(<200-300 \mathrm{~km}^{2}\right)$.

Opciones de estrategia de manejo de material leñoso en pequeñas cuencas $\left(<200-300 \mathrm{~km}^{2}\right)$.

ped to trap floating logs in mountain rivers. Rope net barriers (figure 7B) are designed for storing gravel and wood in small streams, and have been tested with physical modeling and also in the field (Rimbock 2004). The important design features include the height of the net (which is based on the gradient of the torrent), the potential amount of wood to be entrapped and the design discharge (Rimbock 2004). Cable filter dams (figure 7C) are composed of harmonic steel cables $(\varnothing \sim 10 \mathrm{~cm})$ fixed on the river banks by tie-beams. A buttress can be located in the river centerline in order to reduce the cables span. This configuration forces the trapped wood to accumulate towards the river banks where it can be removed during floods. Two of these structures have recently been built along Sarca River (Italian Alps, Trento) and have demonstrated to efficiently exert a filtering action even during a severe flood (recurrence interval $=50$ years) with intense wood transport.

Intervention strategies for the considered cases. In the very populated Alpine region, wood recruitment and trans- 


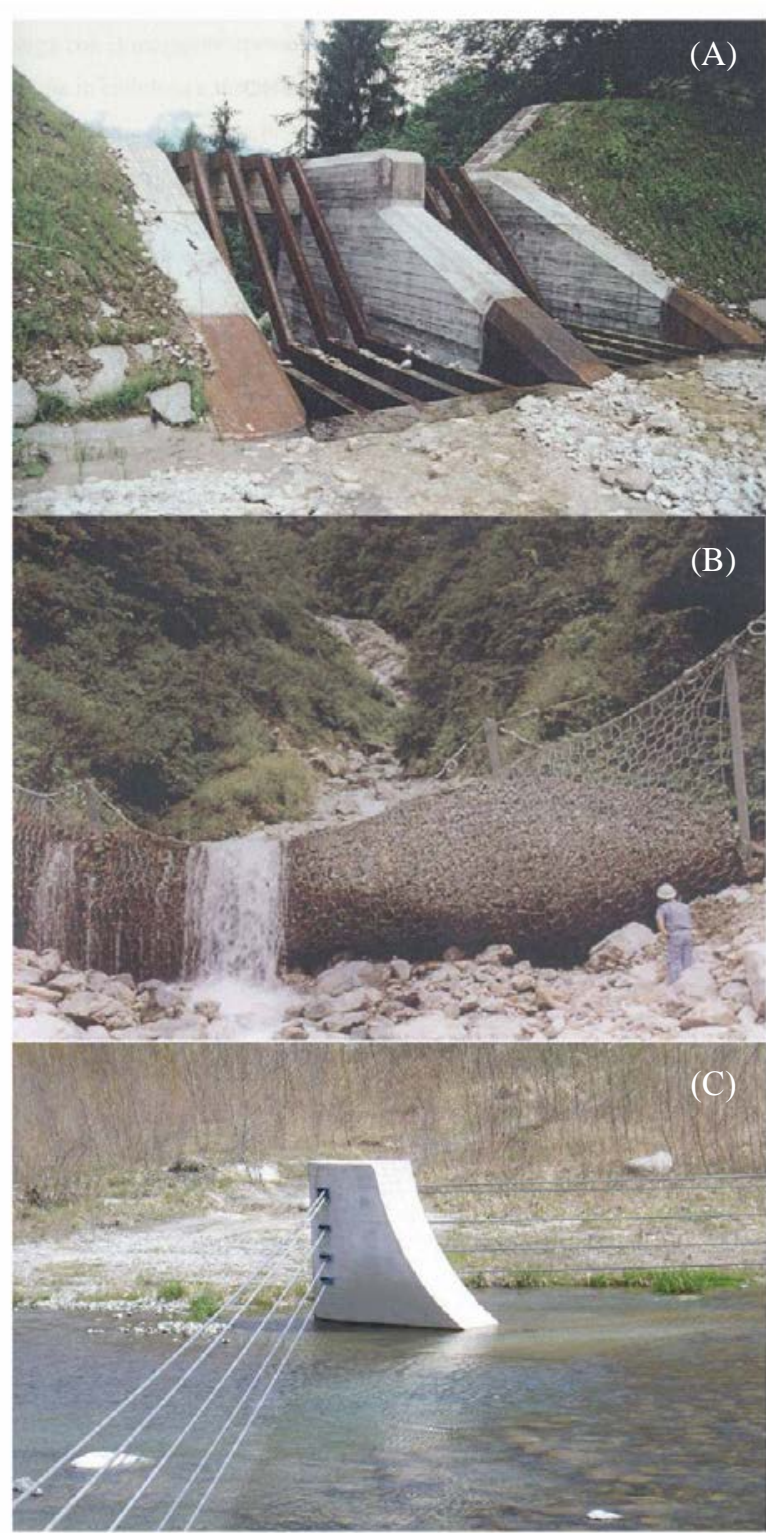

Figure 7. Wood retention control works: a filter concrete check dam (A), a rope net barrier (from: www.geobrugg.com) (B) and a cable filter dam (C).

Ejemplos de obras de retención de material leñoso: un dique filtrante abierto (A), un dique de red de acero (B), y un dique de cables (C).

port have been recently considered in modeling hazard mapping (e.g. Mazzorana et al. 2009, 2011, Rigon et al. 2012). However, these models require the availability of detailed maps of landslide prone areas, land use and forest vegetation typologies, as well as precise DEMs of the river network and hydrologic models (Mazzorana et al. 2009, 2011, Rigon et al. 2012). Due to its relatively reduced urbanization and shorter history of data collection, these records are rarely available in the southern Andean region and thus the approach to in-channel and potential incoming wood is here approached in a conceptual way. The study basins and the proposed management strategies are thus presented as paradigmatic of different conditions of in-channel wood availability, basin conditions and potential hazards in the southern Andean region.

In the case of the Tres Arroyos basin, the high number of pieces and large volume of in-channel wood, associated with widespread land instabilities (debris-flows and landslides due to a wildfire in 1930's) are likely to cause large quantities of wood to be transported during high-magnitude flow events. Indeed, a 1992 intense flood produced severe damage to the road at the outlet of the basin. Local people living on the alluvial fan of Tres Arroyos reported that massive quantities of wood were transported to the alluvial fan, and claimed that a surge flow -i.e. a dam-break - originated from the breaching of a temporary wood dam which occurred during the event. Thus, due to the presence of immovable infrastructures and a main road on the alluvial fan, it is recommended their prompt protection with a cable filter dam located before the apex of the alluvial fan, although this would encourage local people to build more structures, since even the 1992 catastrophic floods discouraged them to build new settlements.

The case of Río Toro is different because of the sparse amount of LW in the main channel. Although a recent (2002) wildfire which burned almost the entire old-growth forest, due to the time lag between the wildfire and the consequent hillslope instabilities (Zelt and Wohl 2004), Rio Toro is still not exhibiting landslides or debris flows carrying massive amount of sediments and dead wood to the main channel. However this may be expected to occur more frequently over the coming decades. Given the virtual absence of human infrastructures in this basin it would be preferable to avoid any intervention. In case human settlements should have to be protected along the main channel, the structural intervention would likely require the building of filter check dams with a composite double inclined slope of the steel filtering elements. This particular type of filter check dam is designed to break debris flow fronts and to retain the coarser pieces of LW, which could create massive unstable and hazardous valley jams.

In the sub-Antarctic climatic conditions of Tierra del Fuego, the Buena Esperanza basin features a dense and low-growing forest, which supplies the main channel with abundant, relatively small logs, frequently organized into valley jams and log steps. Dam-break events due to wood accumulations are a major concern in Tierra del Fuego, both in channels hosting many beaver ponds which may represent potential hazards in case of dam failure (Butler and Malanson 2005,) and in rare beaver-free streams such as Buena Esperanza where in-channel wood is abundant but of small dimensions. In the specific case of Buena Esperanza, its lower part is completely occupied by the city of Ushuaia, and in the uppermost limit of the city the stream is dammed in order to supply drinking water to its inhabitants. The protection of Ushuaia from sediment sur- 
ges caused by woody debris during high magnitude events seems thus of primary importance. In order to avoid the removing of wood from the main channel, the recommended option is the building of one rope-net barrier just upstream of the water supply station. The choice of the rope-net barrier is driven by the fact that this structure has a reduced visual impact, is very flexible, will retain wood and sediments of reduced dimensions and can be easily emptied by a jib crane located just upstream of the water supply station.

\section{CONCLUSIONS}

In-channel logs, especially when organized in jams, play an important geomorphic role in streams because of their effects on flow hydraulics, pool formation and sediments storage, ecological diversity and complexity. LW can also act to reduce the effects of damagingly high flow rates and sediment slugs during flooding. The three analyzed Southern Andes basins show that very large variations in the volume of LW per unit of streambed area occur even within single streams, and that massive inputs may result from slope instabilities adjacent to the channels. Major differences in wood abundance exist due to the basins' disturbance history, and great wood volumes (i.e. $>1,000 \mathrm{~m}^{3} \mathrm{ha}^{-1}$ ) can occur in basins disturbed by fires followed by mass movements and debris flows. In-channel wood in Andean basins is a precious resource for stream stability and ecological status which should be preserved. However, hazards linked to in-channel wood might likely depend on local inputs of whole portions of forested slopes adjacent to the channels due to mass wasting processes. Therefore, prevention and monitoring of hillslope instabilities become critical aspects of flood hazard mitigation also in relation with wood transport, and removal of riparian vegetation is more effective than frequent, and not economically and ecologically sustainable. Wood-trapping structures should be installed upstream of sensitive locations only in the case of high risk to human settlements and infrastructure.

\section{ACKNOWLEDGMENTS}

This research was funded by the EU Project INCOCT-2004-510735 "Epic force" (Evidence-based policy for integrated control of forested river catchments in extreme rainfall and snowmelt). All colleagues and students who helped in the field are greatly thanked.

\section{REFERENCES}

Abbe TB, DR Montgomery. 2003. Patterns and processes of wood debris accumulation in the Queets river basin, Washington. Geomorphology 51: 81-107.

Andreoli A, F Comiti, L Mao, A Iroume, MA Lenzi. 2008. Evaluación de los volúmenes y de los efectos hidro-morfoló- gicos del material leñoso en dos torrentes andinos (Chile). Ingeniería del Agua 15:189-204.

Berg N, A Carlson, D Azuma. 1998. Function and dynamics of woody debris in stream reaches in the central Sierra Nevada, California. Canadian Journal of Fisheries and Aquatic Sciences 55: 1807-1820.

Butler DR, GP Malanson. 2005. The geomorphic influences of beaver dams and failures of beaver dams. Geomorphology 71: 48-60.

Chen X, X Wei, R Scherer, D Hogan. 2008. Effects of large woody debris on surface structure and aquatic habitat in forested streams, southern interior British Columbia, Canada. River Research and Applications 24: 862-875.

Chin A, MD Daniels, MA Urban, H Piegay, KJ Gregory, W Bigler, AZ Butt, JL Grable, SV Gregory, M Lafrenz, LR Laurencio, E Wohl. 2008. Perceptions of wood in rivers and challenges for stream restoration in the United States. Environmental Management 41: 893-903.

Collier KJ, JN Halliday. 2000. Macroinvertebrate-wood associations during decay of plantation pine in New Zealand pumice-bed streams: stable habitat or trophic subsidy? Journal of the North American Benthological Society 19: 94-111.

Comiti F, A Andreoli, MA Lenzi, L Mao. 2006. Spatial density and characteristics of woody debris in five mountain rivers of the Dolomites (Italian Alps). Geomorphology 78: 44-63.

Comiti F, A Andreoli, L Mao, MA Lenzi. 2008. Wood storage in three mountain streams of the Southern Andes and its hydro-morphological effects. Earth Surface Processes and Landforms 33: 244-262.

Donoso C. 1981. Ecología Forestal. El bosque y su Medio Ambiente. Santiago, Chile. Editorial Universitaria. 369 p.

Faustini JM, JA Jones. 2003. Influence of large woody debris on channel morphology and dynamics in steep, boulder-rich mountain streams, western Cascades, Oregon. Geomorphology 51: 187-205.

Fox M, S Bolton. 2007. A regional and geomorphic reference for quantities and volumes of instream wood in unmanaged forested basins of Washington State. North American Journal of Fisheries Management 27: 342-359.

Gerhard M, M Reich. 2000. Restoration of streams with large wood: Effects of accumulated and built-in wood on channel morphology, habitat diversity and aquatic fauna. International Review of Hydrobiology 85: 123-137.

González ME, TT Veblen, JS Sibold. 2005. Fire history of Araucaria-Nothofagus forests in Villarrica National Park, Chile. Journal of Biogeography 32: 1187-1202.

Gurnell AM, H Piegay, FJ Swanson, SV Gregory. 2002. Large wood and fluvial processes. Freshwater Biology 47: 601619.

Kail J, D Hering, S Muhar, M Gerhard, S Preis. 2007. The use of large wood in stream restoration: experiences from 50 projects in Germany and Austria. Journal of Applied Ecology 44: 1145-1155.

Marcus WA, RA Marston, CR Colvard, RD Gray. 2002. Mapping the spatial and temporal distributions of woody debris in streams of the Greater Yellowstone Ecosystem, USA. Geomorphology 44: 323-335.

Mazzorana B, A Zischg, A Largiader, J Hubl. 2009. Hazard index maps for woody material recruitment and transport in alpine catchments. Natural Hazards and Earth System Sciences 9: 197-209. 
Mazzorana B, J Hubl, A Zischg, A Largiader. 2011. Modelling woody material transport and deposition in alpine rivers. Natural Hazards 56: 425-449.

McIlroy SK, C Montagne, CA Jones, BL McGlynn. 2008. Identifying linkages between land use, geomorphology, and aquatic habitat in a mixed-use watershed. Environmental Management 42: 867-876.

Nakamura F, FJ Swanson. 1993. Effects of coarse woody debris on morphology and sediment storage of a mountain stream system in Western Oregon. Earth Surface Processes and Landforms 18: 43-61.

Rigon E, F Comiti, MA Lenzi. 2012. Large wood storage in streams of the Eastern Italian Alps and the relevance of hillslope processes. Water Resources Research 48, W01518. DOI:10.1029/2010WR009854.

Rimbock A. 2004. Design of rope net barriers for woody debris entrapment. Introduction of a design concept. In International Symposium Interpraevent 2004. Riva del Garda, Italy. p. 265-276.

Rinaldi M, C Simoncini, H Piegay. 2009. Scientific design strategy for promoting sustainable sediment management: The case of the Magra River (Central-Northern Italy). River Research and Applications 25: 607-625.

Ulloa H, A Iroume, MA Lenzi, A Andreoli, C Álvarez, V Barrera. 2011. Material leñoso de gran tamaño en dos cuencas de la Cordillera de la Costa de Chile con diferente historia de uso del suelo. Bosque 32(3): 235-245.

Vera M, C Jara, A Iroumé, H Ulloa. 2012. Organic matter retention and diversity of benthic communities influenced by in-stream large wood in a third-order channel in the Coastal Mountain Range, Chaihuín, Chile. In Conference Book, IUFRO Landscape Ecology Conference, Sustaining humans and forests in changing landscapes, Forest, Society and Global Change. Concepción, Chile. $5^{\text {th }}$ to $12^{\text {th }}$ November 2012. p. 111.

Wohl E, JR Goode. 2008. Wood dynamics in headwater streams of the Colorado Rocky Mountains. Water Resources Research 44, W09429. DOI:10.1029/2007WR006522.

Zelt RB, EE Wohl. 2004. Channel and woody debris characteristics in adjacent burned and unburned watersheds a decade after wildfire, Park County, Wyoming. Geomorphology 57: 217-233.

Recibido: 21.06 .12

Aceptado: 07.10.13 